\title{
O LUGAR E A PAISAGEM COMO CATEGORIAS ANALÍTICAS PARA O ESTUDO DAS PRÁTICAS SOCIAIS E TURISMO NO MUNICÍPIO DE IRATI-PR
}

\section{PLACE AND LANDSCAPE AS ANALYTICAL CATEGORIES FOR THE STUDY OF SOCIAL PRACTICES AND TOURISM IN THE MUNICIPALITY OF IRATI-PR}

\author{
Maycon Luiz Tchmolo \\ Mestre em Gestão do Território \\ Unicentro \\ mayconlt@hotmail.com \\ Nicolas Fioriani \\ Doutor em Meio Ambiente e Desenvolvimento \\ UEPG \\ nicolas@uepg.br \\ Patrícia Denkewicz \\ Especialista em Mídias na Educação \\ Unicentro \\ patriciadenkwicz@hotmail.com
}

\begin{abstract}
Resumo
Os objetivos deste artigo são: Investigar as (in) congruências entre o planejamento turístico para o município de Irati-PR e as práticas sociais de apropriação e valorização das paisagens vividas pelos moradores, enquanto patrimônio coletivo da população local. Verificar empiricamente os graus de valorização das paisagens vividas no cotidiano da população iratiense, em termos de matrizes valorativas dos lugares; comparar os pontos/atrativos destacados no projeto de planejamento turístico com as paisagens vividas pelos moradores iratienses. Os procedimentos metodológicos versam na aplicação de um questionário para a população local; e registro fotográfico das paisagens mencionadas nos questionários pelo morador local. Como resultado percebeu-se que as paisagens fomentadas para o turismo são, de certo modo, semelhantes às paisagens cotidianamente vividas e, onde, a população local realiza suas práticas sociais.
\end{abstract}

Palavras-chaves: paisagem; lugar; turismo; práticas sociais, Irati.

\begin{abstract}
The objectives of this article are: To investigate the (in) congruence between tourism planning for the city of Irati-PR and social practices of appropriation and appreciation of landscapes experienced by residents, while the collective heritage of the local population. Empirically verify the degree of appreciation of the landscapes of the population lived in the daily iratiense in terms of matrices evaluative places; compare the points / attractions highlighted in tourism planning project with the landscapes encountered by residents iratienses. The methodological procedures Versam in a questionnaire for the local population, and photographic record of the landscapes
\end{abstract}


mentioned in the questionnaires by local resident. As a result it was found that landscapes promoted for tourism are, in a sense, like the landscapes and daily lived, where the local population realizes their social practices.

Keywords: landscape; place; tourism; social practices, Irati.

\section{INTRODUÇÃO}

As relações entre homem e espaço surgem e renascem no cotidiano e em vários estágios de sua existência, inclui-se assim o "tempo no espaço experiencial" (TUAN, 1983, p. 132). Com base em Kozel (2007, p. 115) “o espaço não é somente apreendido através dos sentidos, ele referenda uma relação estabelecida pelo ser humano, emocionalmente de acordo com suas experiências espaciais. Assim o espaço [...] é vivido". Por isso, o homem é antes de tudo, um sujeito que vivencia o espaço em suas alterações, sejam elas relativas a qualquer experiência ou necessidade própria ou coletiva.

Essa concepção de espaço vivido, no espaço-tempo, parte de aportes filosóficos e psicológicos, os quais são extraídos da experiência humana no mundo. A analogia feita por Jean Piaget, dos estágios de desenvolvimento de uma pessoa, contribui para compreender como um sujeito se relaciona com o espaço. Segundo o pensador, a experimentação ativa é um processo que permite construir o conhecimento de uma criança, contudo essa ainda não forma seus conceitos: tem a experiência, mas formulará conceitos em estágios seguintes do seu desenvolvimento (PIAGET, 1995).

Foucault (1999) traz antemão, uma menção inerente à relação espaço-tempo quando analisa as gêneses dos conhecimentos científicos sobre a natureza, isto é, as formulações de causa e efeito dos fenômenos naturais ligados por analogias e metáforas à experiência humana no tempo e no espaço: o espaço envolve o homem por todos os lados, e ao mesmo tempo o sujeito transmite e propaga suas analogias.

A experiência, portanto, é o princípio dos estudos sobre a organização espacial, da Geografia humanista. O tempo torna-se relevante para essas discussões, pois as experiências relativas ao ser humano são dadas em certa época de seu ciclo vital. Tanto a psicologia como a filosofia são ciências que auxiliam nesse pensar e assim caracterizar o espaço vivido. 
A partir desses pressupostos, o escopo desta pesquisa é elucidar as práticas sociais ${ }^{1}$ cotidianas realizadas no município de Irati-PR, confrontando sobre possíveis lugares e paisagens que são utilizados tanto para essa finalidade, quanto para o desenvolvimento e receptação de turistas para a localidade em questão. Assim sendo, traçam-se os seguintes objetivos: Investigar as (in) congruências entre o planejamento turístico para o município de Irati-PR e as práticas sociais de apropriação e valorização das paisagens vividas pelos moradores, enquanto patrimônio coletivo da população local. Verificar empiricamente os graus de valorização das paisagens vividas no cotidiano da população iratiense, em termos de matrizes valorativas dos lugares; comparar os pontos/atrativos destacados no projeto de planejamento turístico com as paisagens vividas pelos moradores iratienses.

Os procedimentos metodológicos versam na aplicação de um questionário para a população local; e registro fotográfico das paisagens mencionadas nos questionários pelo morador local. A aplicação do questionário com o morador local conta com 12 (doze) questões, sendo 1 (uma) fechada e 11 (onze) abertas, com a finalidade de compreender a ligação do morador iratiense com o seu lugar vivido, bem como quais são as paisagens cotidianamente percebidas e que por algum motivo são representativas para ele dentro do município. Essa coleta de dados foi realizada nos meses de agosto e setembro de e entre os meses de novembro de 2011 a janeiro de 2012.

Portanto, estruturalmente esse artigo se dividirá em três capítulos: o primeiro apresenta aportes teóricos sobre lugar (como principal categoria de análise da pesquisa), a partir de duas visões: da Geografia Crítica/Marxista e da Geografia Humanística/Cultural; ora, o segundo capítulo, traz breves informações sobre o município de Irati, bem como fotos dos principais atrativos divulgados pela organização do turismo municipal; e, o terceiro, apresenta a pesquisa empírica, ou seja, os dados e as concepções coletadas juntamente com o morador iratiense, tendo em vista elucidar as práticas sociais cotidianas da população.

\section{DISCUSÃO TEÓRICA}

2.1 Do espaço ao lugar: concepções de geografia crítica (do global ao local) e da geografia humanística (experiências e simbolismos) 
Mas, afinal, qual é o significado de lugar na Geografia? Embora, essa seja uma questão aparentemente simples, ela torna-se dificultosa de responder, pois o conceito de lugar segue duas linhas epistemológicas de pensamento: o da Geografia Crítica (positivismo) ou Dialética Marxista e da Geografia Humanística com aportes culturais. Com base em Johnston (1991), Harvey (1996) e Santos (1993 e 1997) citado por Ferreira (2000) a Geografia Crítica compreende o lugar como um panorama do local (regional) para o global, uma dialética a partir da construção social e suas relações com espaço, tempo e ambiente. E a Geografia Humanística tem por base a existência humana, a partir das experiências cotidianas e os significados do mundo para o individuo; "buscando uma aproximação com a Fenomenologia e o Existencialismo" (FERREIRA, 2000, p. 66).

Por um lado, pela visão positivista da Geografia, Santos (2006, p. 213) entende o lugar como um ambiente individualizado, com conotação entre a singularidade local e a pluralidade global: "cada lugar é, à sua maneira, o mundo. [...] Mas, também, cada lugar, irrecusavelmente imerso numa comunhão com o mundo, torna-se diferente dos demais. A uma maior globalidade, corresponde uma maior individualidade." Ainda Santos (2006) segue mencionando de G. Benko (1990) denominou esse fenômeno como "globalidade", expondo, dessa maneira, a complexidade de tratar teoricamente sobre lugar.

Carlos (1996, p. 16) define o termo como: "o ponto de articulação entre a mundialidade em constituição e o local, enquanto especificidade concreta e enquanto momento." Nesse sentido, a compreensão de lugar para a dialética marxista contém parâmetros de uma dinâmica única de produção, a qual foi formada através de seus processos históricos e culturais locais, e a alienação capitalista que este lugar possui diante a globalização. Santos (2008, p. 113) diz que "nas condições atuais, o cidadão do lugar pretende instalar-se também como cidadão do mundo. A verdade, porém, é que o 'mundo' não tem como regular os lugares”. A essa crítica feita por Santos, entende-se que os lugares são frutos além de uma particularidade produtiva e histórica, de uma multiplicidade global, ou seja, os lugares possuem traços que lhe tornam únicos, que são representados e vividos pela comunidade, outrora são envolvidos pelas inovações lançadas e produzidas pela dinâmica capitalista, de modo que não há como normalizar ou variar um sujeito enquanto dissipa outros lugares. 
Harvey (1992) ressalta que pelas execuções do sistema capitalista, o conhecimento do espaço passou a ser abrangente e de fácil acesso para todos os sujeitos, fazendo com que assim os lugares ficassem vulneráveis as influências do mundo. Então, entende-se que, para essa corrente de pensamento geográfico, o conceito de lugar passa por uma dialética, que é unilateral, do local para o global, do particular para o geral, pois o lugar é dotado de simbolismos individualizados ou coletivos, entretanto, e ao mesmo tempo, existem outros lugares que por ações mercadológicas excitam o psicológico social.

A partir da racionalidade introduzida pelo modo organizacional vigente ocorrem mutações nos lugares, e esses se transformam em territórios consubstanciados. Por exemplo, um pequeno hotel familiar localizado na Amazônia oferece aos turistas alojamentos rústicos, serve sua gastronomia típica e apresenta o seu artesanato local. Ora, uma grande rede hoteleira se instala nesse ambiente, ocasionando assim, uma variância na prestação e na disposição dos produtos e serviços oferecidos, não excluindo, talvez, a tipicidade e as características locais, mas impactando na fisionomia paisagística, nos modos da cultura tradicional, na degradação do patrimônio históricocultural pelo excesso de turistas e, sobretudo, na vulnerabilidade econômica, pois os indivíduos daquele hotel, que um dia foram protagonistas, serão coadjuvantes no seu próprio lugar; aquém, ainda, dos casos que estes dependem se subordinar à chegada dessa contemporaneidade que altera a dinâmica dos fluxos e dos fixos anteriores, alterando as relações socioespaciais locais.

Quanto a isso, Santos (1991) salienta e exemplifica que:

[...] a chegada do novo causa um choque. Quando uma variável se introduz num lugar, ela muda as relações preexistentes e estabelece outras e todo o lugar muda. Por exemplo, quando se constrói um hotel com 400 lugares, muda todo o lugar e não apenas o setor hoteleiro (SANTOS, 1991, p. 99).

A essa visão holística, dialética e crítica, característica de geógrafos com inspiração marxista, o lugar não se individualiza somente pela subjetividade individual ou coletiva de uma sociedade (uma das linhas de pensamento de geógrafos humanistas/culturais, que será exposto), e sim por todas as ações oriundas naquele local, que interferem social, cultural, histórica, ecológica, econômica, religiosa e politicamente. Portanto, um dos vieses do pensamento marxista diante ao conceito e as 
características de lugar é a globalização, a qual intervém nos processos modais do local e conduzem para uma centralidade global e uma racionalidade dominante.

Por outro lado, para a Geografia Humanística, o lugar é entendido como um ambiente simbólico de um indivíduo, onde a partir de suas experiências cotidianas ele dota de valor e significado. (TUAN, 1983). O lugar adquire importância plural na vivência de um sujeito ou coletividade, baseada nas suas experiências cotidianas, onde é conferido afeto e caracterizado simbolismo, pois anterior a um ambiente onde procedem aos processos multifacetados (econômicos, culturais, religiosos, tecnológicos etc.), o lugar é um núcleo onde são saciadas as necessidades materiais e imateriais de um ser humano. Tuan (1983, p. 4) entende que "os lugares são centros aos quais atribuímos valor e onde são satisfeitas as necessidades biológicas de comida, água, descanso e procriação", ou então, "lugar é uma pausa no movimento. Os animais incluindo os seres humanos descansam em uma localidade porque ela atende a certas necessidades biológicas. A pausa permite que uma localidade se torne um centro de reconhecido valor". (TUAN 1983, p. 153)

Em outra acepção Relph (1980, p. 39) diz que:

O lugar é o fundamento de nossa identidade como indivíduos e como membros da comunidade, o lugar onde habita o ser. O lar não é só o lugar em que você está feliz por viver, ele não pode estar em toda parte, não pode ser trocado, é um centro de significados insubstituível.

Buttimer (1985, p. 228), que busca a compreensão de lugar a partir da Fenomenologia relacionando com a Geografia, salienta que o lugar é a soma das “dimensões simbólicas, emocionais, culturais, políticas e biológicas." A partir das significações múltiplas e das experiências vividas em um lugar é que os fenomenólogos analisam o lugar enquanto conceito geográfico. As concepções denotam o lugar como um delimitado espaço, onde os indivíduos e grupos confinam todas as suas relações entre si e com o ambiente externo, sendo que cada indivíduo prevalece nesse habitat sentimentos particulares, podendo ser de algo tangível ou intangível.

Buttimer (1995, p. 178) diz que um sujeito rodeia-se por grupos centrais no espaço vivido, porém podem existir locais “[...] qualitativamente diferentes de todos os outros, tais como o lugar do nascimento do homem, ou as cenas do seu primeiro amor, ou certos lugares da primeira cidade estrangeira que visitou quando jovem". Ou seja, a 
pessoa está inserida em contexto social vivenciado cotidianamente, contudo ela possui lembranças de lugares transpassados, que podem (ou não), serem mais singulares que o seu espaço vivido. Deste modo, o lugar (como sinônimo, também de espaço vivido) surge como conceito relevante para a concepção das experiências humanas no espaço.

Em sua obra intitulada La Poética del Espacio, Gastón Bachelard (2000) faz referências que a nossa residência é o nosso "canto do mundo", ali que temos nossas primeiras experiências, ali que abrimos os olhos para conhecer o mundo: Porque la casa es nuestro rincón del mundo. Es se ha dicho con frecuencia nuestro primer universo (BACHELARD, 2000, p. 28). Deste modo, a casa, como referencia o autor, significa o ambiente de vivência dos seres humanos, assim podemos fazer uma analogia com o lugar como conceito geográfico, pois as menções fenomenológicas (como essa) que contribuíram para os geógrafos de inspiração humanista fazerem suas considerações e definirem seus conceitos sobre lugar.

Tuan (1983, p. 37) salienta que "o lugar pode adquirir profundo significado para o adulto através do contínuo acréscimo de sentimento ao longo dos anos." Essa significação do lugar surge interiorizada no indivíduo, é uma essência particular, a qual é formada durante as etapas de sua vida, baseia-se então num processo temporal.

Quando se vivencia um lugar, constantemente, surgem significados diferentes para determinado sujeito. Pode-se exemplificar, portanto, que a representação e o valor de um município, enquanto um lugar é diferente entre os habitantes, ora, também, destes para os visitantes da localidade. Há um significado interno, realçado no psicológico de cada sujeito. Claval (2007, p. 55) diz que "os lugares não têm somente uma forma e uma cor, uma racionalidade funcional e econômica. Eles estão carregados de sentido para aqueles que os habitam ou que os freqüentam". Ainda ressalta que as pesquisas realizadas por psicólogos acerca disso são relevantes para a compreensão da valia de um lugar para um indivíduo.

Tuan (1983) entende que uma das formas de se definir lugar parte da notoriedade de um determinado objeto, "lugar é qualquer objeto estável que capta nossa atenção" (TUAN, 1983, p. 179). Porém, ele entende que existem lugares dotados de significado para um sujeito ou coletividade que possuem mínimo valor visual, entretanto estes consistem emocionalmente e não pelo "olho crítico ou da mente" (TUAN, 1983, p. 180). Deste modo, Wanderley e Menêzes (1996, p. 174) dizem que "os 
lugares são, portanto, núcleos de valor, que atraem ou repelem em graus variados os indivíduos e os grupos".

Embora, a distinção entre as maneiras de se conceituar lugar, da Geografia Crítica e da Geografia Humanística, existe autores que conseguem desenvolver a definição harmoniosamente, entre as duas correntes de pensamento. De acordo com Ferreira (2000) é relevante focar tanto no aspecto subjetivo, quanto no objetivo, logo “[...] será colocar-se em algum lugar no meio do caminho entre a visão descentrada do cientista, que vê o lugar com um conjunto de relações genéricas, e aquela centrada do sujeito que o vê em relação às preocupações do indivíduo" (FERREIRA, 2000, p. 76). Da mesma forma, Yázigi (2001, p. 38) entende o lugar com certa similitude: "reconheço o lugar como uma arrumação que produz o singular, mas estimo que de modo algum se poderá entendê-lo ou trabalhá-lo sem a consideração da extensão de seus sistemas. Ele tem uma personalidade sim, mas não é sujeito." Ou seja, a dimensão do lugar é aquém de suas peculiaridades, pois existe um sistema mais abrangente e complexo.

Conceituar lugar subsidia ao entendimento da multiplicidade de fatores que emergem da relação sujeito(s)-espaço(s): tanto no que se diz respeito aos processos globais que interferem nas produções locais e com a sua homogeneização de um lugar, quanto ao que diz respeito às experiências cotidianas do ser humano, da valorização universal do seu espaço habitado e semantizado, as paisagens vividas.

\section{RESULTADOS}

\subsection{Irati-PR: os principais atrativos turísticos}

De acordo com o censo do IBGE (2010) Irati possui uma população de 56.207 habitantes, distribuídos em uma unidade territorial de 999,519 km², e com uma densidade demográfica de 56,23 habitantes por $\mathrm{km}^{2}$. Pode-se notar um notável crescimento populacional urbano no município, em comparação a década de 1950, sendo que 44.932 pessoas residem na área urbana $(79,94 \%)$ e 11.275 na área rural $(20,06 \%)$. Os moradores do sexo feminino representam 50,7\% da população (28.499 mulheres) e a masculina 49,3\% (27.708 homens). 
Os atrativos turísticos no município de Irati cingem a algumas reflexões se exatamente são pontos turísticos ou podem ser entendidos como espaços determinados para uma determinada prática social. Através de documentos observados sobre os atrativos turísticos do município encontram-se algumas áreas que são entendidas com potencial para promoção e divulgação turística.

\section{- Imagem de Nossa Senhora das Graças}

Esse monumento pode ser considerado o único atrativo localizado na área central da cidade. Por ter status da maior imagem de Nossa Senhora das Graças do mundo (figura 1), com 22 metros de altura, atrai indivíduos interessados pelo turismo religioso. Também, atrai muitos moradores que veem a estátua como uma protetora da cidade, por meio da sua fé religiosa. A prática religiosa é o que mais se percebe no local. O espaço conta também com um centro de informações turísticas, onde são vendidos produtos produzidos por artesãos locais, com um mirante que se avista todo o centro e alguns bairros da cidade, e com um playground.

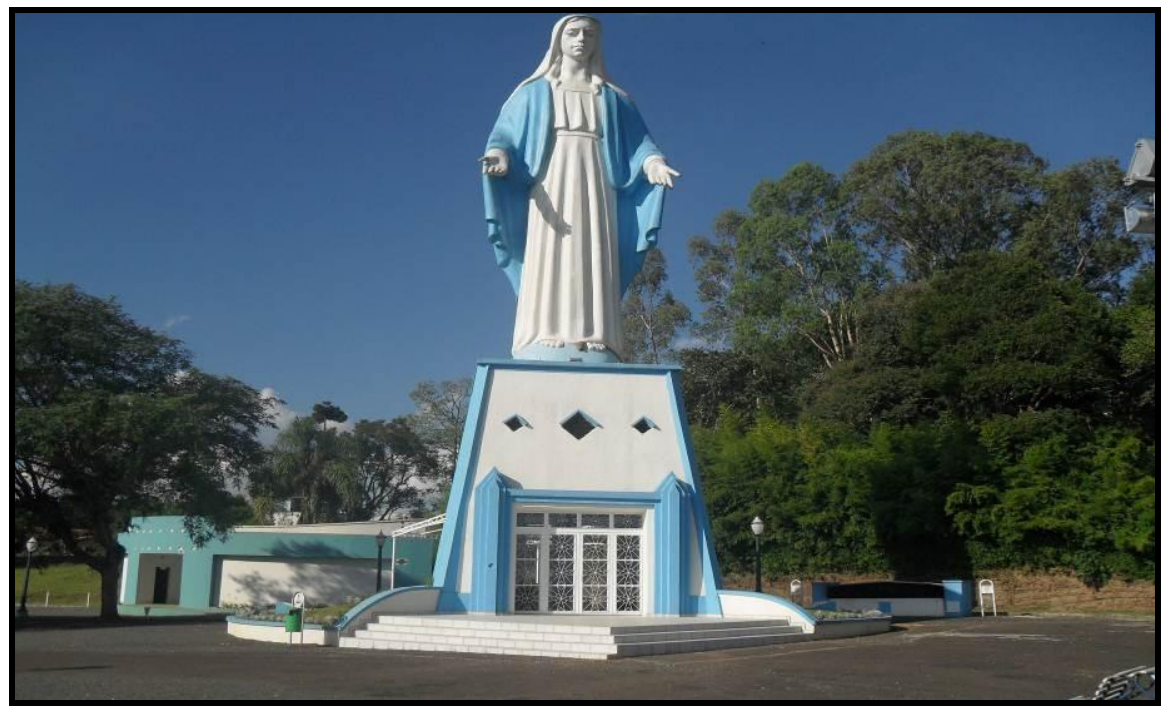

Figura 1 - Imagem de Nossa Senhora das Graças Fonte: TCHMOLO (2012)

\section{- Parque Aquático e de Exposições Santa Terezinha}

O Parque Aquático é um ponto de práticas sociais, onde parte da população iratiense exerce atividades físicas, bem como serve para um local de passeio familiar, lazer e entretenimento. Este espaço (figura 2), localizado no Bairro Rio Bonito, possui área de 79 mil m² e consta com: lago, um pavilhão de exposição, com 1.017,5 m², uma 
mini-estação ferroviária, canchas de areia para prática esportiva, pista de cooper e ciclismo com 1.050 metros, pedalinhos, academia ao ar livre para adeptos e playground.

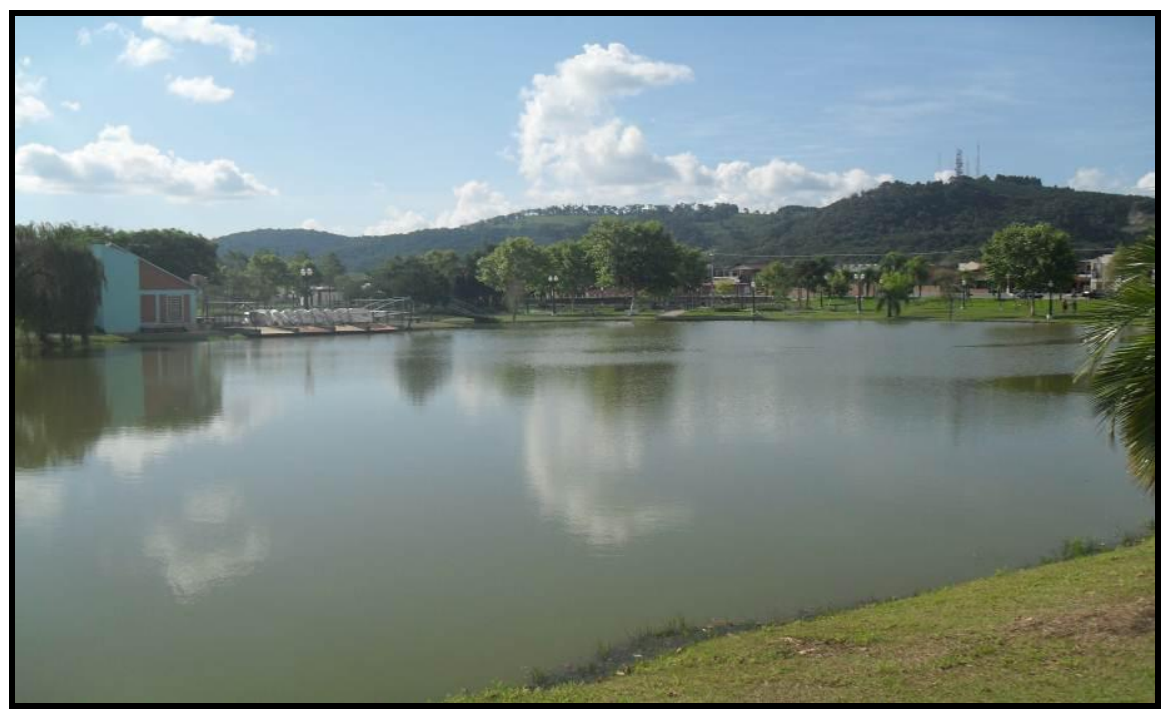

Figura 2 - Vista parcial do Parque Aquático Fonte: TCHMOLO (2012)

\section{- Caverna do Canhadão}

Essa caverna apesar de seu potencial turístico, não recebe muitas visitações. Segundo a PMI ela vem sendo visitada somente por escolas e pela Secretaria da Agricultura do Município. Ela está localizada em uma propriedade particular, a $30 \mathrm{~km}$ da sede municipal, sendo que se para chegar a esse ponto é necessário percorrer $1 \mathrm{~km}$ em meio à mata fechada. Possui 48 metros de largura por 52 metros de comprimento (figura 3).

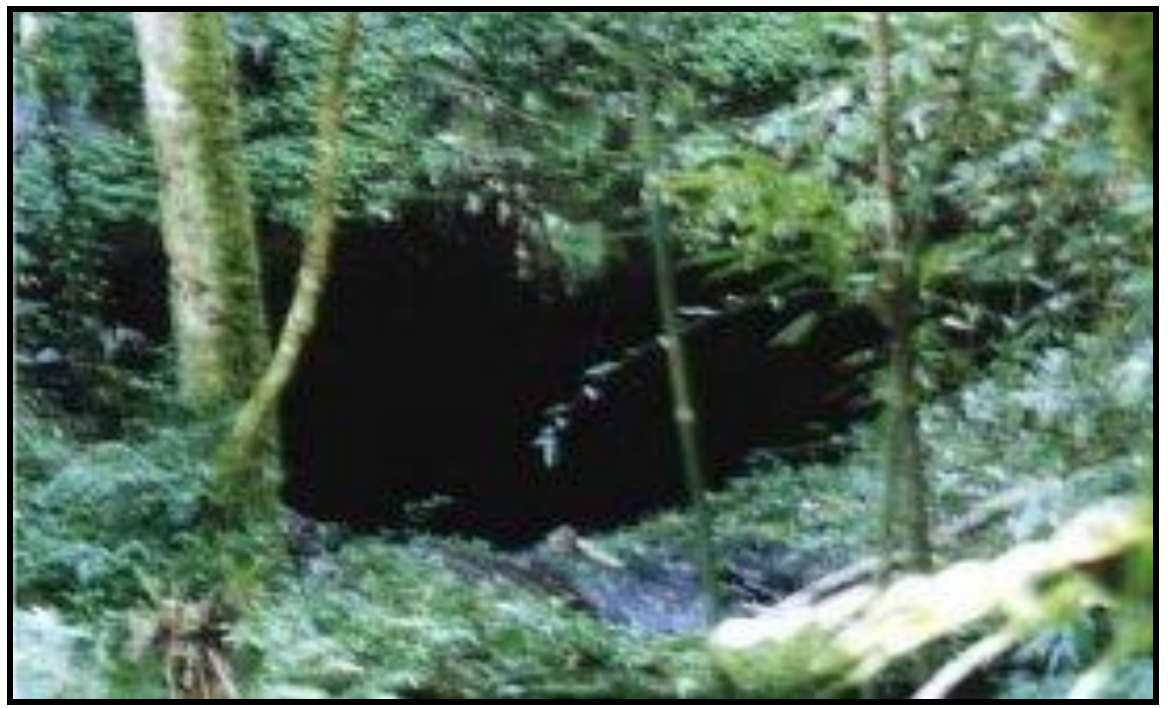

Geo UERJ - Ano 15, $\mathrm{n}^{\circ} .24$, v. 2, $2^{\circ}$ semestre de 2013 ISSN: 1415-7543 E-ISSN: 1981-9021 http://www.e-publicacoes.uerj.br/index.php/geouerj 
Figura 3 - Caverna do Canhadão

Fonte: PMI (2010)

\section{- Floresta Nacional de Irati (FLONA)}

Apesar de ser denominada Floresta Nacional de Irati (figura 4) e fazer parte dos atrativos turísticos do município, a localização desta é na área territorial de Fernandes Pinheiro, cidade limítrofe de Irati. Fica a $6 \mathrm{~km}$ da sede municipal. A visitação turística só pode ser realizada através de um comunicado prévio.

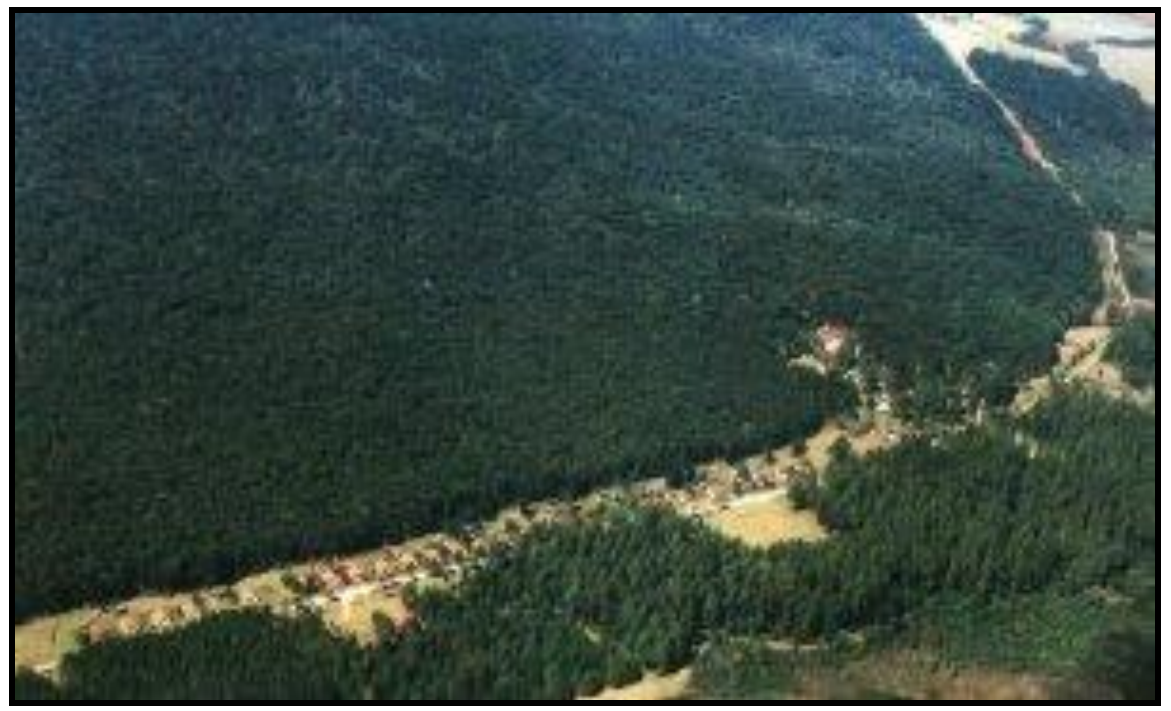

Figura 4 - Vista aérea da FLONA

\section{- Cachoeiras}

Fonte: PMI (2010)

As cachoeiras são espaços turísticos potenciais e relevantes dentro do município, contudo não são exploradas pelo turismo. Esses locais recebem mais habitantes da própria cidade que se deslocam para tais em busca de descanso.

A única cachoeira localizada próximo ao centro da sede municipal é denominada Recanto Rubens Dallegrave (Figura 5). As outras cachoeiras divulgadas para o turismo no município são: Cachoeira do Itapará, a $45 \mathrm{~km}$ da cidade (figura 6); Cachoeira do Cadeadinho, a $36 \mathrm{~km}$ da cidade (figura 7); Cachoeira do Faxinal dos Antônios, a $44 \mathrm{~km}$ da cidade (figura 8); e Cachoeira do Teodózio Hlatki, a $45 \mathrm{~km}$ da cidade (figura 9). 


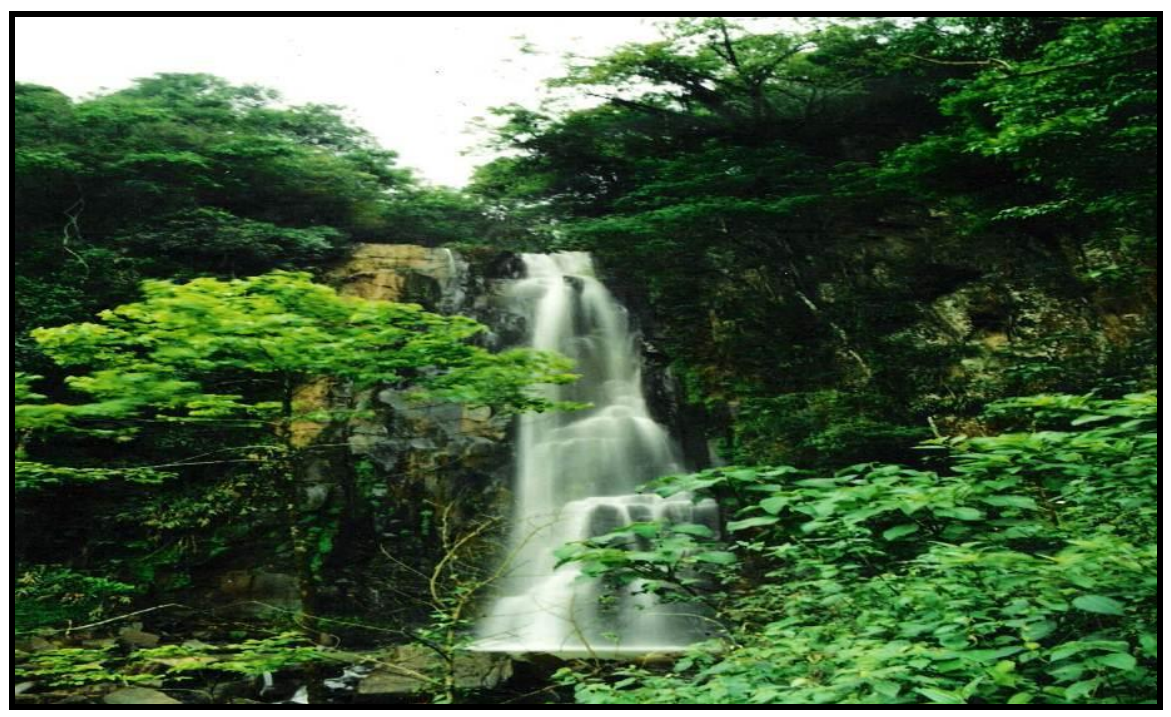

Figura 5 - Recanto Rubens Dallegrave (Cachoeira do Fillus) Fonte: PMI (2010)

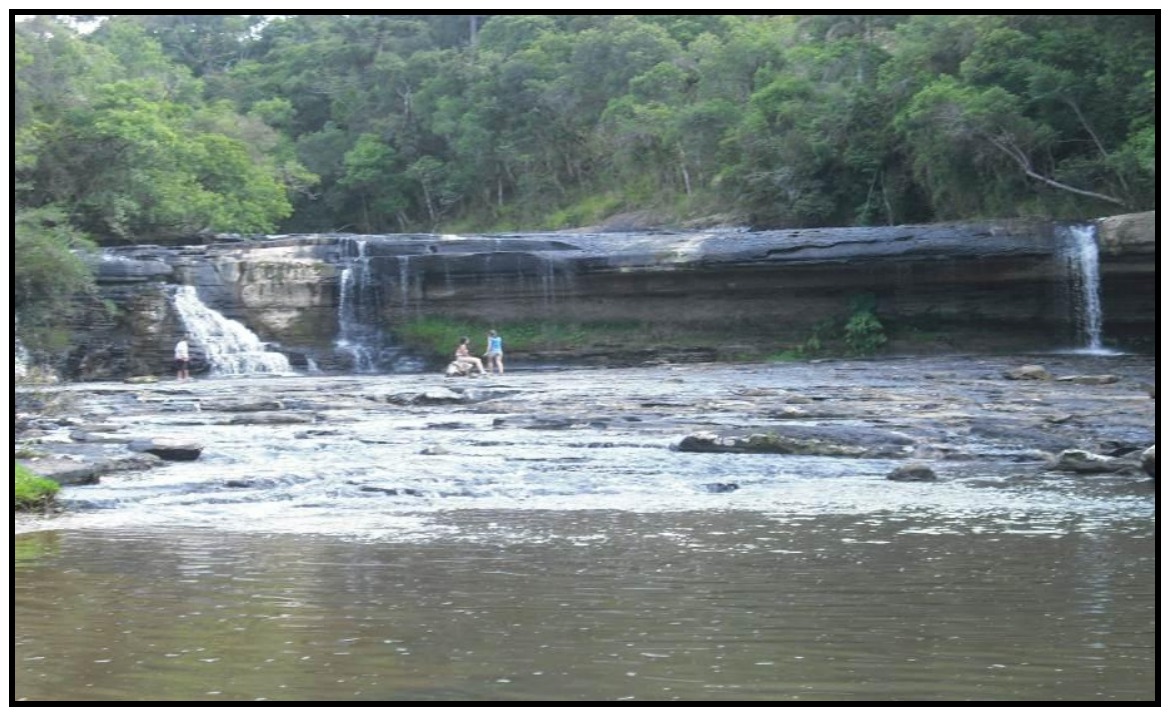

Figura 6 - Cachoeira do Itapará

Fonte: TCHMOLO (2012)

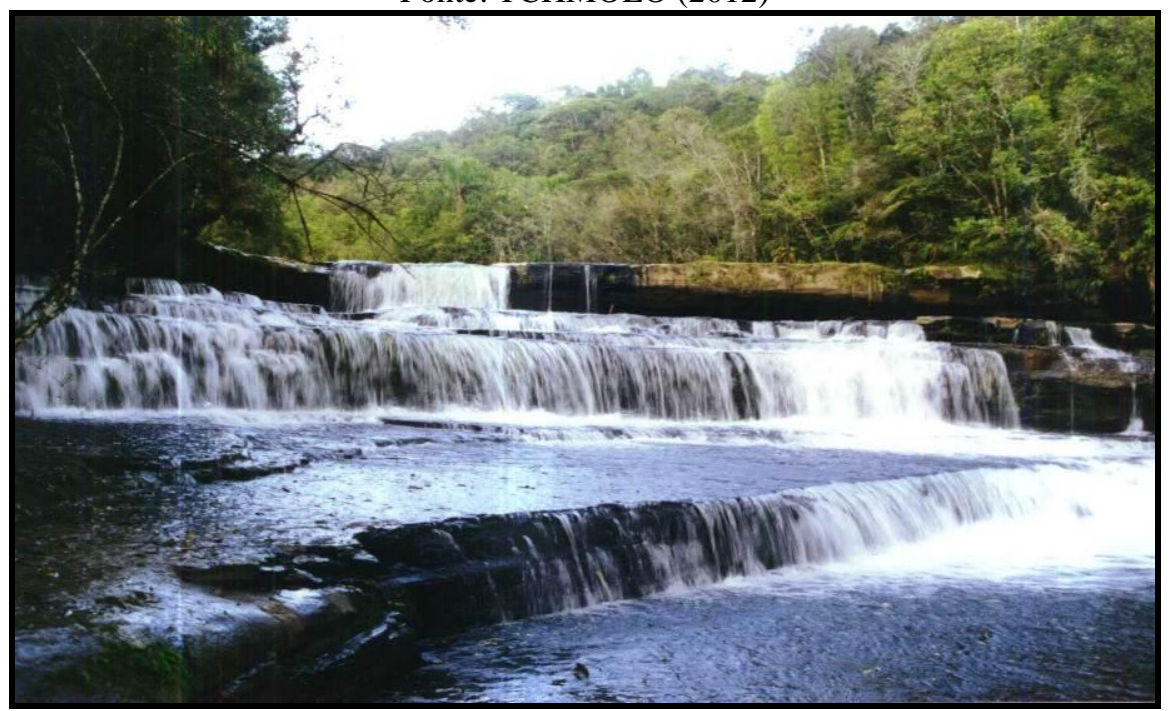

Geo UERJ - Ano 15, n'. 24, v. 2, $2^{\circ}$ semestre de 2013

ISSN: 1415-7543 E-ISSN: 1981-9021

http://www.e-publicacoes.uerj.br/index.php/geouerj 
Figura 7 - Cachoeira do Cadeadinho Fonte: PMI (2010)

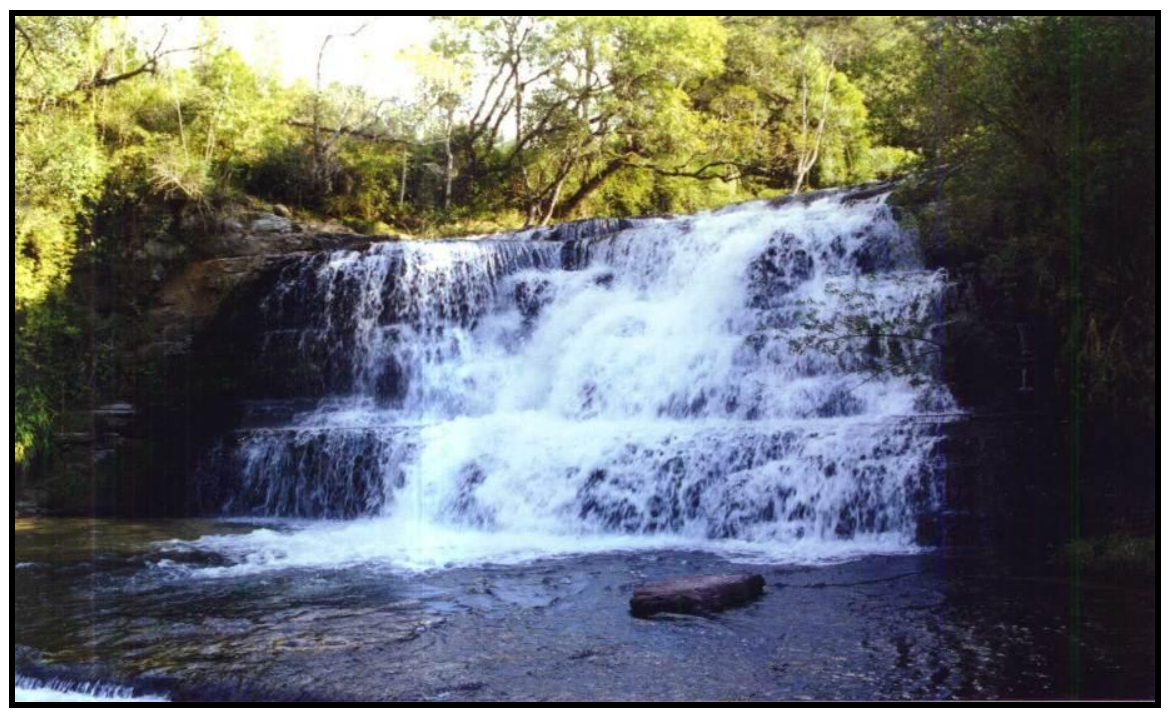

Figura 8 - Cachoeira do Faxinal dos Antônios Fonte: PMI (2010)

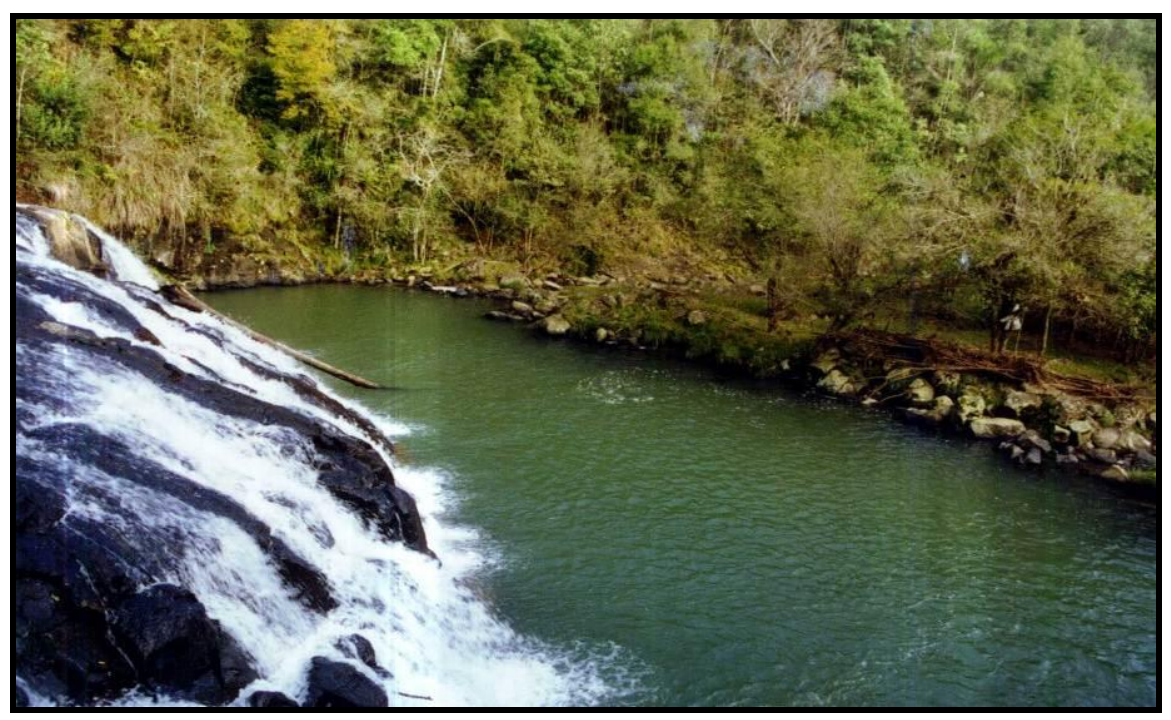

Figura 9 - Cachoeira do Teodózio Hlatki Fonte: PMI (2010)

Esses são os principais atrativos, pontos ou paisagens turísticas de Irati.

Percebe-se que há um emaranhado de segmentos turísticos que possuem potencialidade no município, como o turismo em áreas naturais, o turismo histórico, o turismo religioso, o turismo de lazer e entretenimento e o turismo cultural.

\subsection{Elucidação das práticas sociais cotidianas em Irati-PR : lugar e paisagem:}


Relacionam-se, neste momento, os dados coletados empiricamente com as abordagens teóricas sobre lugar e paisagem. Juntamente, procura entender a ligação entre os pontos turísticos de Irati e as práticas sociais neles realizadas. Deste modo, a sistematização será desenvolvida a partir das questões aplicadas aos residentes. Ao invés do termo paisagem, procurou usar o termo lugar. Essa decisão tomou, por conta, o contexto de paisagem não ser bem assimilado a partir de um senso comum. Quando se trata de paisagem concebe-se uma imagem, uma foto ou, então, um recurso natural como, por exemplo, uma árvore. Deste modo, com a utilização de lugar as pessoas poderiam expressar-se melhor no que realmente apreciam e valoram em Irati.

\section{- O Senhor (a) gosta de viver em Irati? Por quê?}

O pertencimento ao lugar não se faz somente se uma pessoa mora naquela localidade. Muitos indivíduos vivem em determinado município, contudo estão ali somente por obrigações, geralmente, trabalhistas. Outros entrevistados veem em cidades interioranas, como Irati, dificuldades para realizar seus desejos e objetivos profissionais e de lazer, como nos casos de R. L. (22 anos, mora no Bairro Rio Bonito): "Não gosto de morar aqui, por oferecer poucas oportunidades de trabalho e divertimento." E de C. M. (44 anos, mora no Centro): "Moro em Irati, porque a minha família mora aqui, senão moraria em outra cidade".

Ora, Machado (1996, p. 113) fala que "gostar de um bairro, por exemplo, não obriga necessariamente a pessoa nela permanecer ou predominantemente, preferir suas facilidades e serviços." Assim, ocorre que: não é porque a pessoa reside naquela localidade, que obrigatoriamente ela gostará dali.

Santos (2000, p. 81) diz que "cada homem vale pelo lugar que ele está [...] seu valor vai mudando, incessantemente, para melhor ou para pior, em função das diferenças de acessibilidade [...] independentes da sua própria condição.” Deste modo, a visão do morador de uma localidade, pode ser (ou não) atual. Talvez, em épocas anteriores ele possuía prazer de viver na cidade. Entende-se, então, que o relatado por ele passa por uma questão de momento, como salienta Milton Santos. A família, também, é um diferencial nas escolhas de uma pessoa, pois por mais saturada que ela esteja da cidade, são seus filhos e cônjuge que fazem a pessoa morar no local. De acordo com Machado (1996, p. 113) “[...] para aqueles que viveram muitos anos em um lugar, a familiaridade engendra aceitação e até afeição". 
Os motivos por gostar de viver em Irati são assinalados por: a cidade ser tranqüila, ser "pequena", ser acessível a centros maiores e por não ter a agitação dos grandes centros. A. S. G. (22 anos, mora no Centro): “Gosto de morar em Irati, pois considero uma cidade tranquila, fácil de morar devido a não ter muitas dificuldades para chegar aos determinados locais, sendo de fácil locomoção. [...] Levo em conta também a questão da cultura na cidade".

É senso comum pensar que o município ainda está conseguindo manter esses traços de cidade interiorana, com um povo tradicionalista e com boa segurança. Esse seria um dos motivos do crescimento populacional da cidade, sendo que pessoas se deslocam de outros centros para residir em Irati. Acerca disso D. L. (64 anos, mora no Bairro DER) menciona: “Apesar de Irati estar crescendo eu gosto muito de morar aqui. É uma cidade que a gente pode ir fazer tudo a pé, porque é tudo perto." Do mesmo modo, J. F. L. (18 anos, mora no Bairro Rio Bonito) expõe: “É bom morar nesta cidade. O crescimento é inevitável, porém é um lugar com bastante possibilidades de emprego e lazer".

\title{
- Quais os lugares o Sr (a) aprecia em Irati? Qual é o mais apreciado e o menos?
}

$\mathrm{Na}$ procura de identificar as paisagens realmente apreciadas pela população iratiense, percebeu-se uma similaridade com aquelas fomentadas para o turismo. Parque aquático, Morro da Santa, Cachoeiras foram veemente citadas pelos entrevistados. R. L. (22 anos, mora no Bairro Rio Bonito) indicou aquela paisagem que mais lhe agrada e aquela menos apreciada: "Aprecio o lugar onde se localiza as torres de transmissão e o menos apreciado seria o Morro da Formiga".

Bem como, B. L. M. (21 anos, mora no Centro):

\begin{abstract}
Meu local preferido é a estátua da Nossa Senhora das Graças, em cima do morro e o parque aquático. Acho inconveniente o fato do trilho do trem passar no centro da cidade, porém o que mais me incomoda é o fato do córrego que passa próximo a Santa ser poluído e ter cheiro desagradável.
\end{abstract}

Estas considerações podem ser relacionadas concepções de topofilia e topofobia (TUAN), mencionados no subcapítulo 2.1. Ou seja, a topofilia como a ligação entre o lugar e/ou a paisagem e seus moradores, aquilo que visualmente lhe agrada, o simbolismo dotado perante um elemento do espaço (TUAN, 1980). E a topofobia como aquela "paisagem do medo" que é escondida diante um planejamento municipal, devido seu diminuto apelo mercadológico (AMORIM FILHO, 1996).

Geo UERJ - Ano 15, n⿳⺈.24, v. 2, $2^{\circ}$ semestre de 2013

ISSN: 1415-7543 E-ISSN: 1981-9021

http://www.e-publicacoes.uerj.br/index.php/geouerj 
Para P. F. C. (32 anos, mora no Bairro Canisianas):

Aprecio o bairro onde moro, a praça em frente ao Ivasko (mercado da cidade) da entrada da cidade, o Parque Aquático (menos aos domingos). Gosto muito de ir até o Gonçalves Junior aprecio o caminho que liga Irati a Gonçalves Júnior. Não aprecio o Morro da Santa e o Parque Aquático aos domingos.

A aversão do entrevistado aos dois principais atrativos da cidade (Morro da Santa e Parque Aquático) é por ele explicada devido ao acúmulo excessivo de pessoas nos finais de semana, pois a maioria das vezes o que se vê não são pessoas utilizando deste espaço para apreciar, fazer orações (como é o caso do Morro da Santa) ou, então, descansar e desfrutar de lazer (exemplo do Parque Aquático), mas para ingerir bebidas alcoólicas e ouvir música em volume alto.

Outro entrevistado (R. G. 55 anos, mora no Jardim Califórnia) vê em Irati uma cidade que pode ser contemplada em sua totalidade: "Gosto de quase todos os lugares nessa cidade. Mas o que acho de mais belo são as cachoeiras do Pinho de Baixo e de Itapará. Acho bonito, também, a Santa".

Entre os jovens entrevistados percebeu-se que outras paisagens apreciadas são aquelas de utilização noturnas, como bares, restaurantes, casas noturnas, etc. Embora, a indicação das paisagens turísticas, esses jovens utilizam com mais assiduidade às paisagens noturnas, do que as voltadas para o turismo. Isso confirma o que os autores da fundamentação teórica falam sobre a percepção: esta não se dá somente pelas sensações visuais do lugar (sons, olfato), mas, também, contribuem para tal. Havendo explicações de ordem psicossocial e etária para a apreciação de um lugar: o simbolismo que uma paisagem noturna exerce na população jovem de hábitos urbanos, pode contrariamente não ser percebido pela mesma população jovem na parte matutina, por exemplo. Mas é um fato relevante e que deve ser incentivado como prática social, a exemplo do que ocorre no bairro La Florida em Buenos Aires, que é um bairro muito frequentado por turistas pela sua atividade noturna.

Entre a população mais velha da cidade, notou-se que há um afeto pelas práticas religiosas, principalmente, por existir um grupo de Terceira Idade no município. Ao mesmo tempo, que são realizados bailes matutinos, geralmente, aos Domingos no Clube Sete, há encontros para excursões, sobretudo, para lugares como, por exemplo, Aparecida do Norte. M. F. A. (68 anos, mora no Bairro São Francisco) diz: “Gosto 
muito da Santa e da São Miguel (Igreja). O Sete também é um lugar que eu gosto. Acho feio em Irati alguns bairros como o Morro da Formiga e a Pedreira, pela pobreza".

Por meio dessa questão foi possível visualizar algumas paisagens e lugares valorados pela população iratiense, contudo não fomentados como um produto turístico do município. É os casos das Igrejas e Casas Antigas do distrito de Gonçalves Júnior (figura 10 e 11), a Estação Ferroviária de Irati (figura 12) e o Ginásio Municipal de Esportes (figura 13). Salvo que o Ginásio de Esportes é um local, onde muitos moradores apreciam praticar esportes (espaço de práticas sociais).

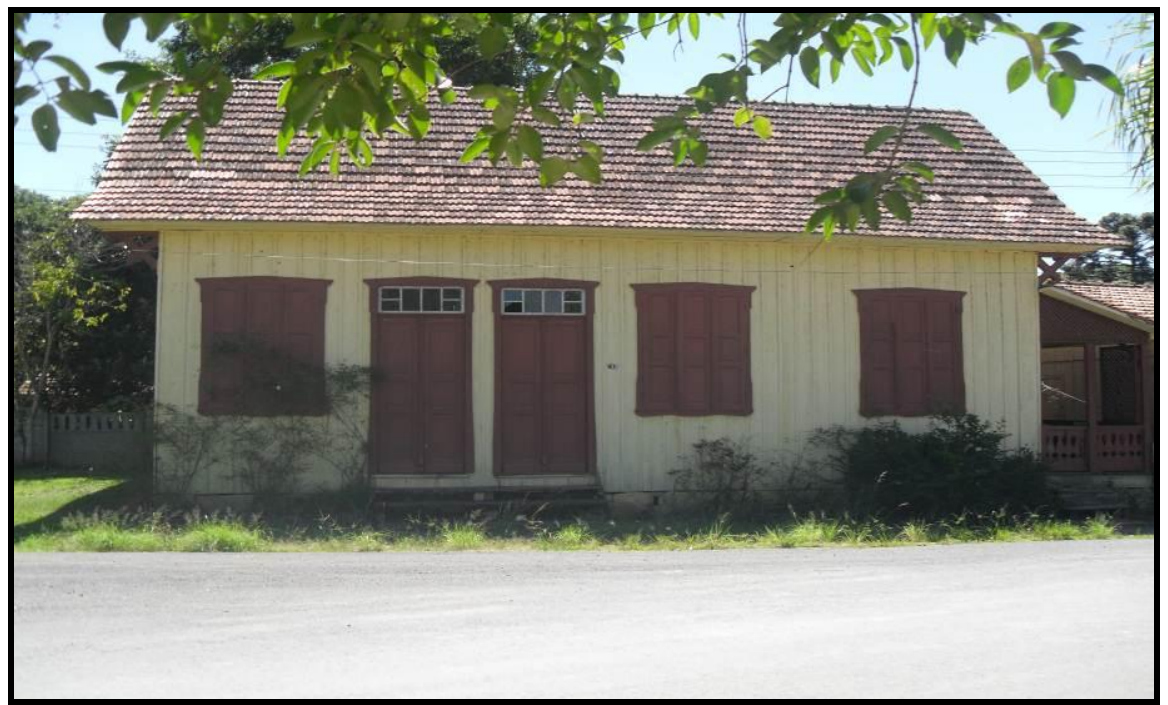

Figura 10 - Casa Antiga no Distrito de Gonçalves Júnior (1908) Fonte: TCHMOLO (2012)

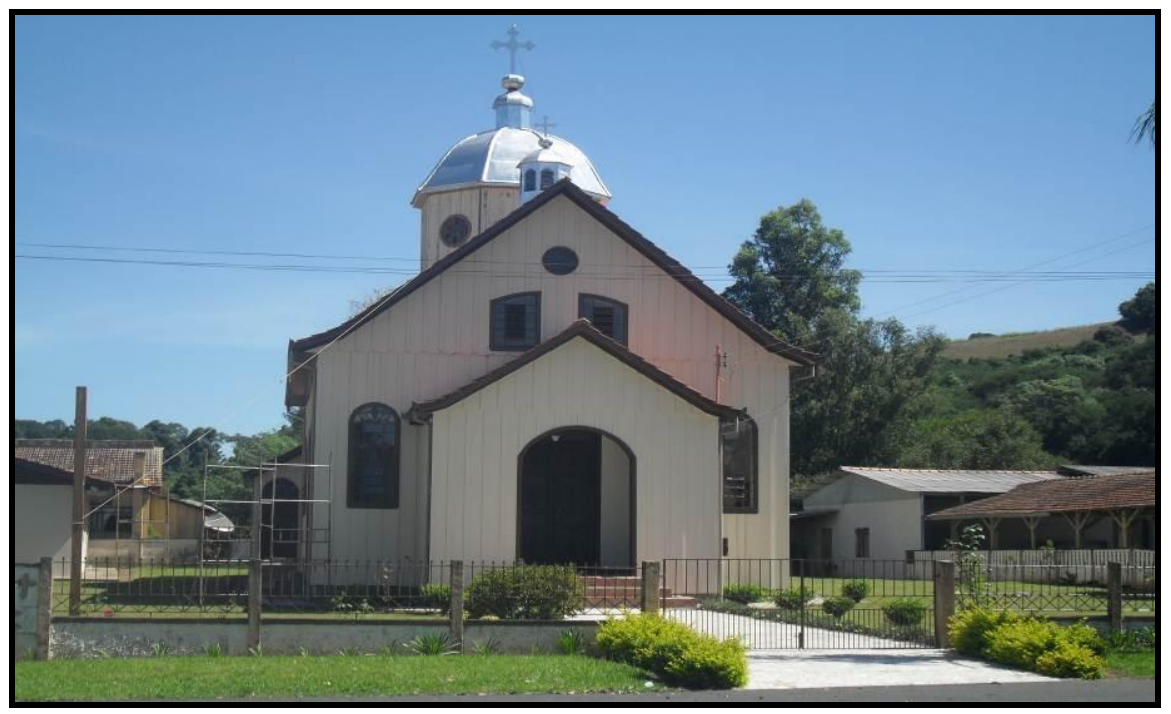

Figura 11 - Igreja São Pedro e São Paulo (Gonçalves Júnior)

Fonte: TCHMOLO (2012) 


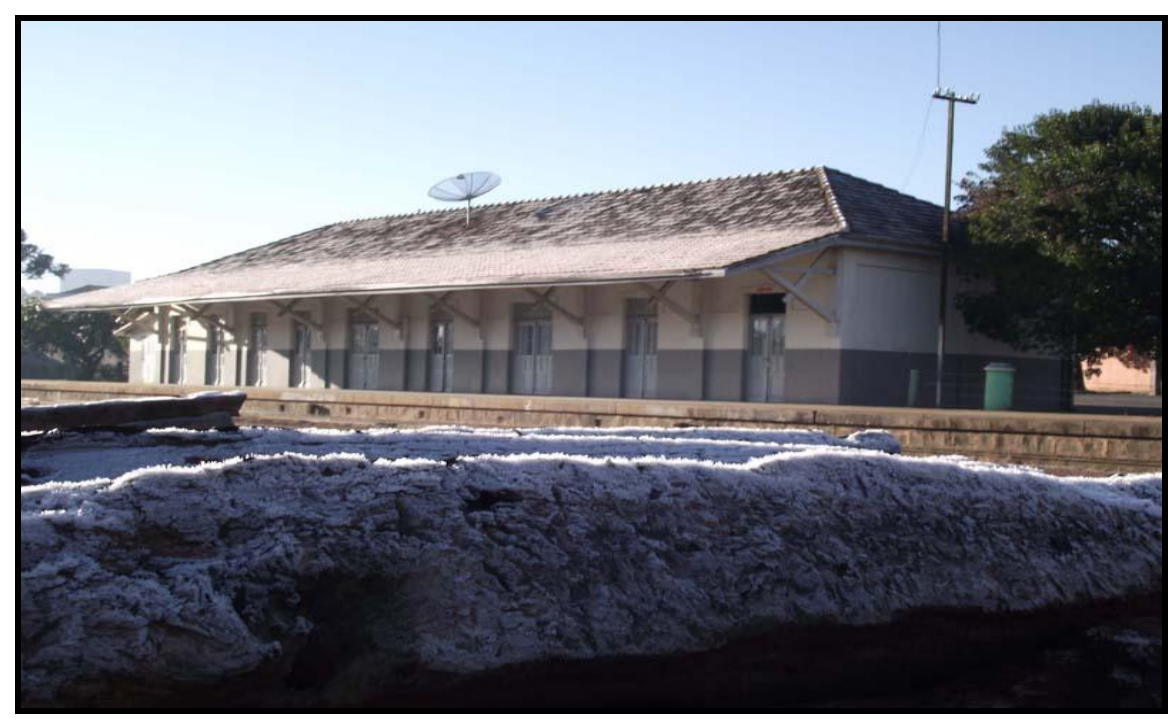

Figura 12 - Estação Ferroviária

Fonte: PMI (2010)

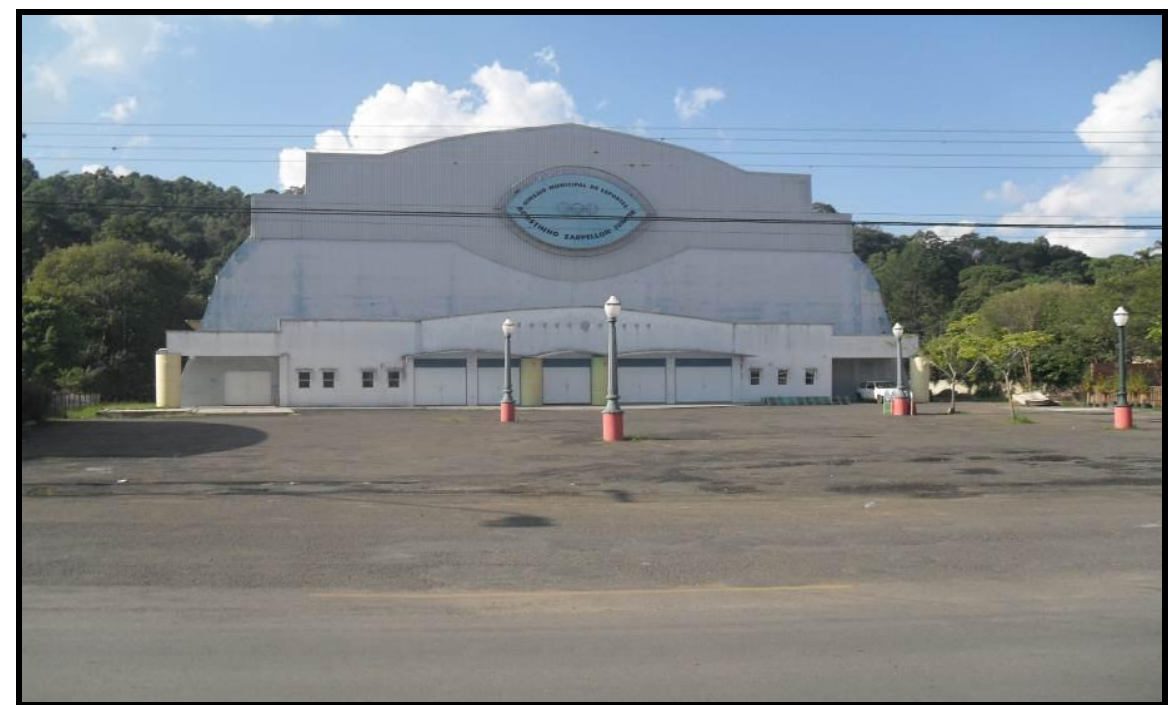

Figura 13 - Ginásio Municipal de Esportes

Fonte: TCHMOLO (2012)

Percebeu-se, a partir da análise das respostas, que a fisionomia da paisagem contribui para as predileções das pessoas, isto é, aquelas que estão com o seu visual preservado e conservado são as mais apreciadas. Segundo Yázigi (2002, p. 13) "Paisagem significava mais um modo de ver do que de agir. [...] Às vezes, a paisagem faz parte do futuro do homem: moramos em cidades ou campos, mas habitamos também paisagens que podem despertar-nos para dimensões superiores às reais".

Nem todas as paisagens que apreciamos, podemos visualizá-la diariamente. Existem paisagens que ficam em nossas memórias, e na primeira oportunidade nos 
esforçamos para poder contemplá-la. Ora, há aquelas paisagens que passamos e convivemos todos os dias. Com base em Relph (1979, p. 7 apud MACHADO, 1996, p. 110) "é nos lugares onde vive e pelo manejo dos campos, rios e pradarias, no curso de sua vida e no movimento de coisas e pessoas, que o homem externa sua relação fundamental com a terra".

\section{- O Sr (a) utiliza esses lugares no dia-a-dia? Sim ou não? Se SIM em que momento} do seu dia? Se NÃO quando utiliza? E, como o Sr (a) utiliza esses lugares? Para que?

\section{Somente passa por eles?}

Portanto, a relação com uma paisagem vem do tempo em que um indivíduo "convive" com ela: "Eu utilizo nos finais de semana e quando é verão para fazer caminhadas no parque. Eu utilizo mesmo pra passeios com a família e caminhadas" (M. E. T. M., 44 anos, mora no Centro). "Não. Visito tais lugares (Parque Aquático, Morro da Santa e Cachoeira do Itapará) ocasionalmente apenas. Eu utilizo para descontração, descanso e diversão." (T. F. 22 anos, mora no Centro). "Vou de vez em quando, geralmente, quando meus parentes vem de Curitiba (Parque Aquático e Morro da Santa)" (O. M. 31 anos, mora no Bairro Canisianas).

No entanto, existem aqueles que utilizam a paisagem frequentemente, como é o caso de B. L. M. (21 anos, mora no Centro): "Sim. Diariamente, durante vários horários. Costumo visitar a Santa quando minha família e amigos querem passear e apreciar a vista da cidade. Vou caminhar com frequência no parque aquático. Como moro no centro, passo várias vezes ao dia pelos trilhos do trem".

$\mathrm{O}$ elo com a paisagem faz com que a pessoa conduza melhor suas atividades diárias: "A paisagem faz parte do dia a dia de todas as pessoas. Mesmo que sem perceber, é a paisagem fonte de inspiração para as atividades diárias [...] Depende da paisagem para ficarmos dispostos e muitas vezes desanimados" (BOLSON, 2004). Em casos a paisagem preservada faz com que ela admire e viva esse elemento do ambiente, caso contrário a um sentimento negativo perante esta.

Alguns indivíduos visualizam as paisagens e lugares, os quais se relacionam diariamente como é o caso dos estudantes da Universidade Estadual do Centro-Oeste (figura 14) ou até mesmo aqueles que trabalham na área central da cidade. F. W. (22 anos, mora no Centro) relata que: "Sim, eu utilizo esse lugar diariamente. Geralmente de manhã cedo, que tenho aula (Unicentro).” A paisagem desta Instituição de Ensino 
Superior traz aparências de tranquilidade, pois é rodeada pela natureza, rica em flora e fauna.

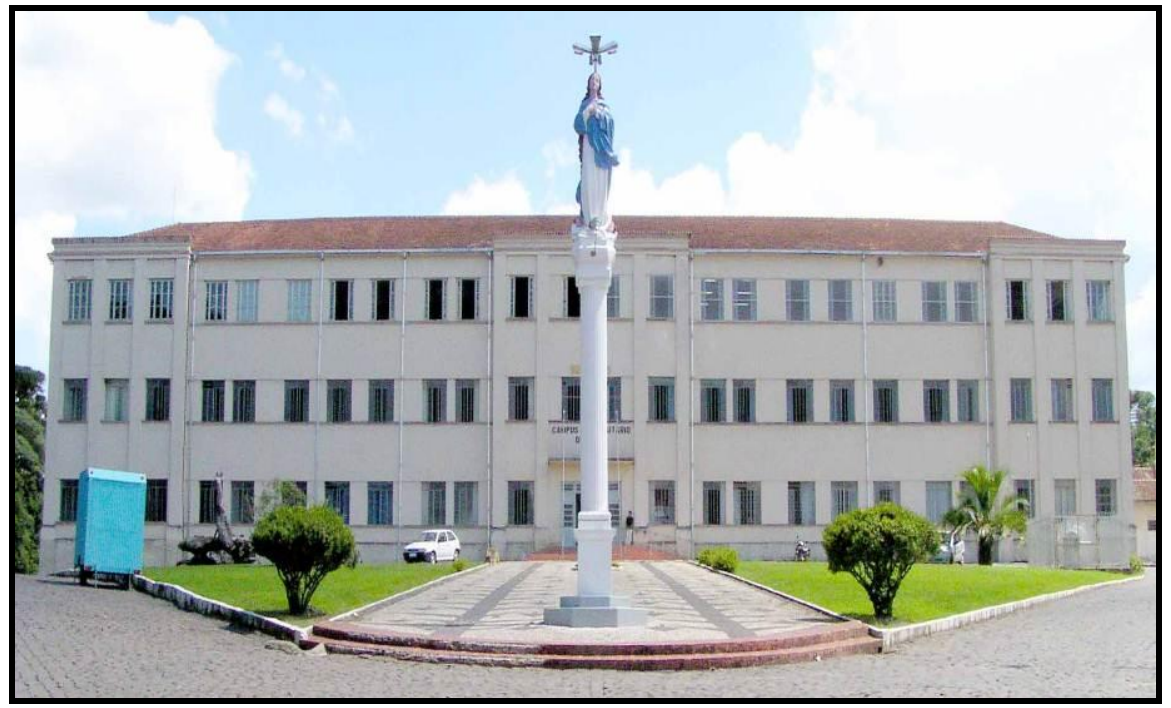

Figura 14 - Universidade Estadual do Centro-Oeste, Campus Irati. Fonte: PMI (2010)

\section{- Onde ficam esses lugares? Em qual bairro?}

A proposta desta questão foi perceber se os moradores conhecem os bairros em que estão inseridas as paisagens, por eles citadas. A partir disso tomou-se os termos reconhecer-se e orientar-se indicados por Paul Claval (2007). Diferentemente do reconhecer-se no lugar, que é exposto por Claval (2007, p. 194), como uma "apropriação do espaço pelo sentido", o orientar-se é compreender onde se localiza determinada paisagem, lugar ou território, ter um senso de direção. $\mathrm{O}$ autor exemplifica alguns sistemas de orientação como, por exemplo, os pontos cardeais ou um mapa. E, ainda, salienta que "a apreensão implica em uma rosa de direções fundamentais e um modo de medir as distâncias que permita definir a posição" (CLAVAL, 2007, p. 194).

Diante, as respostas colhidas, notou-se uma boa acepção das pessoas quanto à localização das paisagens por elas mencionadas. No entanto, a maioria das pessoas somente refletiu por um tempo e mencionou os bairros em que estas paisagens estão inseridas: "A Santa e o trilho do trem ficam no centro" (B. L. M., 21 anos, mora no Centro); "Ficam Bairro Rio Bonito, Morro da Santa e Centro." (M. E. T. M., 44 anos, mora no Centro).

Esse sentido para alguns não se faz eficaz, como se atentam para as palavras de J. R. (39 anos, mora no Conjunto Santo Antônio) "Ah, eu não sei o nome daquele 
bairro, é centro? (em relação à Santa). O Parque fica no Rio Bonito, isso?" Ou então, A. S. G. (22 anos, mora no Centro): "Alguns destes lugares ficam no Centro, os outros não sei qual bairro." Os indivíduos por estarem inseridos numa matriz social, neste exemplo são moradores do Centro da cidade e de um bairro próximo ao centro, não conhecem ou não se interessam em saber em quais locais de uma municipalidade ficam aquelas paisagens apreciáveis. Deste modo, o reconhecimento se faz presente, contudo a orientação é frívola.

Para moradores de bairros mais distantes do centro há dificuldade em reconhecer o bairro que se encontra determinada paisagem ou lugar, como pode ser percebido na pesquisa empírica. Claval (2007) refere-se a esse exercício como orientarse em algum local: "orientar-se consiste em situar os lugares num espaço de referência mais amplo e mais abstrato. [...] Para ir à direção de outro lugar longínquo, invisível e mais suposto que conhecido, é necessário orientar-se” (CLAVAL, 2007, p. 189-194).

\section{- O que elas significam para o $\mathrm{Sr}(\mathrm{a})$ ?}

O significado de uma paisagem remete a valores afetivos (individuais), tradicionais (coletivos), religiosos (sagrados e profanos) e também àqueles atribuídos às experiências cotidianas.

\footnotetext{
A estátua significa a parte religiosa da cidade, como se a Nossa Senhora da Luz estivesse nos abençoando diariamente e nos cuidando, lá de cima. O parque aquático representa o contato com a natureza. $\mathrm{O}$ trilho do trem lembra o passado da cidade e mostra como ela cresceu em volta deste local, gerando alguns inconvenientes (B. L. M., 22 anos, mora no Centro).
}

Nota-se, o valor religioso e de fé das pessoas quando se pergunta da estátua de Nossa Senhora das Graças. O parque aquático e as praças, por exemplo, são lugares que as pessoas procuram para descontrair e passar seu tempo ocioso: "São lugares que eu procuro freqüentar pra passar o tempo.” (A. S. G., 22 anos, mora no Centro).

Existem pessoas que tem uma relação maior e mais intensa com as paisagens inseridas em seu espaço vivido, do que com os próprios seres humanos que lhe rodeiam. Relph (1980, p. 41) diz que "uma relação profunda com os lugares é tão necessária, e talvez tão inevitável, quanto uma relação próxima com as pessoas; sem tais relações, a existência humana, embora possível, fica desprovida de grande parte de seu significado". S. L. L. (24 anos, mora no Bairro Fernando Gomes) ressalta que: 
O ginásio significa um espaço de lazer e entretenimento. Gosto de ir ao ginásio para praticar esportes. A Unicentro significa um centro de aprendizado, aonde além de estudar, a gente pode estar em contato com um lugar belo, cheio de árvores e beleza natural. Já a Santa e o Parque são espaços que significam, ao meu entendimento, como pontos turísticos do município.

Um lugar ou uma paisagem remetem a significados distintos para todas as pessoas entrevistadas. Percebe-se um elo afetivo para aqueles que gostam de praticar esportes com o ginásio de esportes e com espaços para essas atividades como, por exemplo, o Estádio Municipal, o Estádio Fioravante Slavieiro e o Estádio Coronel Emílio Gomes. Outras pessoas dotam um significado maior as práticas religiosas, como é o caso de M. A. T. (45 anos, mora no Bairro Fósforo): “A igreja significa pra mim um espaço de refúgio, onde posso me satisfazer espiritualmente".

A indignação se faz presente também, quando se falam em paisagens não apreciadas na cidade: "O morro da formiga um abandono e a torre um lugar pra relaxar" (R. L. 22 anos, mora no Bairro Rio Bonito). Podemos entender e, consequentemente, relacionar o mencionado pelo entrevistado com a "paisagem do medo" (AMORIM FILHO, 1996), que são aqueles artifícios ocultados da visitação turística, e ao mesmo tempo, esquecido pelo planejamento municipal.

Torna-se necessário salientar, portanto, que "é preciso ancorar-se no fato de que a paisagem interessa antes a seus próprios habitantes e que só numa relação de estima deles pelo espaço é que, eventualmente, despertará o interesse de transeuntes, visitantes, turistas" (YÁZIGI, 2003, p. 70).

A partir desse ponto de vista, percebemos que a indignação e, posterior, reivindicação da população pode mudar a realidade destas "paisagens camufladas", pois somente pelo poder público dificilmente realizará melhorias e apreços. Portanto, entende-se, de certo modo, que o interesse pelo turismo por parte de uma comunidade, pode contribuir para uma diminuição da pobreza, por exemplo, em um bairro como o Morro da Formiga.

Sensibilizados pelas modificações, e a gestão municipal percebendo isso, podese criar um lugar de visitação, com responsabilidade social, cultural e ambiental, o que, consequentemente, estará contribuindo para a melhoria de vida destes moradores.

\section{- Como são esses lugares? Descreva como eles veem a sua mente.}


Desde o início do seu estudo sobre topofilia, Tuan (1980, p. 1) indaga: "Quais são nossas visões do meio ambiente físico, natural e humanizado? Como percebemos, estruturamos e avaliamos? [...] Quais são os laços entre meio ambiente e visão do mundo?". Uma simples resposta, como a de D. P. L. (21 anos, mora na Vila Nossa Senhora da Luz) "Parque e colina são bonitos, mas poderiam ser melhores, quem sabe virarem uma fonte de turismo para região", podem representar um conhecimento empírico profícuo para análise. O entrevistado entende como "lugares ou paisagens bonitas", ou seja, encanta-se com o ambiente natural e/ou construído destes locais, contudo crê na possibilidade de uma melhor estruturação destes locais, citando o turismo como possível agente de avanços.

A partir de um dos sentidos, a visão, a pessoa conhece as paisagens, em congruência desenvolve sentimentos sobre elas, sejam positivas ou negativas. Acerca disso, entende-se que "experiências variadas fazem conhecer e construir a realidade, utilizando desde os sentidos mais diretos (tato, olfato, audição, paladar) até a percepção visual ativa." (MACHADO, 1996, p. 108). Para M. E. T. M. (44 anos, mora no Centro): "O Parque Aquático é um lugar bonito, amplo e transmite tranquilidade. O Morro da Santa, além de ter uma imagem muito bonita de Nossa Senhora das Graças nos dá também uma visão panorâmica de nossa cidade".

Percebe-se a realização de um trabalho intelectual, onde as pessoas procuraram visualizar mentalmente os locais por elas mesmos citados, indicando as virtudes e apreços das paisagens. Tuan (1980, p. 12) entende que: "um ser humano percebe o mundo simultaneamente através de todos os seus sentidos. A informação potencialmente disponível é imensa." Os cinco sentidos contribuem, juntamente com o quadro social que a pessoa está inserida, para suas alegações sobre as paisagens. Existem pessoas que se preocupam veemente com o desenvolvimento e crescimento econômico de uma cidade, outros são mais humanistas, procuram diminuir desigualdades e ajudar as pessoas menos favorecidas, e outros, ainda, que se preocupam com as modificações realizadas no meio ambiente, pessoas com uma visão naturalista. Neste último caso, T. F. (22 anos, mora no Centro) diz que: "São locais agradáveis, não coincidentemente todos respeitam a natureza, arborizados, ou seja, em total respeito, preservação e exaltação do meio ambiente". 
O principal ponto que pode ser destacado, quando as pessoas descreveram os locais mencionados, foi à afeição pelos mesmos. A maioria dos entrevistados elogiou e ressaltou a atratividade dessas paisagens, tanto no que se diz respeito par ao uso da população local, quanto para turistas e visitantes.

- Se um dia esse lugar fosse destruído para fazer uma rua, por exemplo, o que o $\mathrm{Sr}($ a) acharia? $\mathrm{O}$ que o $\mathrm{Sr}$ (a) faria para que ela ficasse onde está? $\mathrm{O} S \mathrm{Sr}$ (a) quer que seus filhos/netos conheçam esse lugar como ela é hoje? Por quê?

Os entrevistados, de uma forma geral, reprovam iniciativas que possam ser feitas, numa possível aniquilação das paisagens por eles mencionadas. Entendem que as paisagens iratienses como, por exemplo, a Imagem de Nossa Senhora das Graças (Morro da Santa), são elementos que caracterizam histórica e culturalmente o povo do município. M. E. T. M. (44 anos, mora no Centro):

\begin{abstract}
Não gostaria. Com certeza esses lugares já fazem parte da história de Irati. Se um dia acontecesse algo a esses lugares, a população se manifestaria e, eu ajudaria nesse protesto. Sim, por fazerem parte da nossa história e, meus netos devem conhecer esses lugares.
\end{abstract}

A preservação foi o ponto focal no levantamento dessa questão. Preservar lugares e paisagens faz com que os indivíduos de um local tenham uma aproximação simbólica com estes, logo exercem um papel de proteção a esses elementos do espaço. A paisagem, portanto, torna-se uma marca da população local. Acerca disso, Castro (2002, p. 124) diz que "[...] sendo uma marca que cada cultura imprime no espaço, [...] a paisagem é um produto coletivo de uma sociedade dotada de um meio e de uma história" (grifo da autora). Assim, a paisagem é um indicador de pertencimento cultural de um povo, faz parte de sua memória coletiva, não somente pelo o que ela é ou como está atualmente, mas, também, e principalmente, diante todos os seus aspectos históricos, que foram enraizados e passados de geração para geração.

M. C. R. (28 anos, moradora da Vila São João) diz que:

Nossa seria um descaso com a população iratiense. Imagine destruir as igrejas de Gonçalves Junior, o que seria da cultura e do povo que mora naquele local? Caso acontecesse isso eu entraria com um abaixo assinado contra os causadores dessa fatalidade e brigaria até o fim. Com certeza, quero que meus netos conheçam esses locais, pois fazer parte da história e cultura de Irati. 
Alguns moradores repudiam qualquer descaracterização que sejam fomentadas nas paisagens. Compreendem que seria um desrespeito ao povo de Irati, bem como um uso indevido das finanças públicas: "Acharia um desperdício de dinheiro público e uma afronta a população. Faria uma mobilização junto à sociedade iratiense e câmara de vereadores. Sim, gostaria que meus netos conhecessem, porque já faz parte da população iratiense”. (C. M., 44 anos, mora no Centro).

Pode-se notar, nesta questão levantada, uma indignação presente da população com o uso indevido dos patrimônios paisagísticos da cidade. Embora, a utilização de algumas paisagens seja, também, de cunho comercial, perante a imagem da paisagem, as pessoas entendem que elas não podem ser destruídas por serem elementos que representam a história e cultura do morador iratiense.

Entretanto, existem casos em que o lugar pode ser modificado, pois de acordo com Yázigi (2001, p. 49) "a estrutura do lugar não pode ser eterna. Mas isto não significa que sua personalidade deva se perder, porque o homem busca a estabilidade do lugar." As alterações sempre ocorrerão, seja essa por intermédio da natureza ou da ação dos homens. O que o ser humano necessita saber que unindo um planejamento que vise revitalizar ou reestruturar determinado local é menos constrangedor e maléfico do que destruir por completo tal.

\section{- Quem deveria ser o responsável para cuidar desse lugar?}

As modificações na paisagem, geralmente, são realizadas com o foco em algum benefício econômico para o município, fazendo assim que suas representações simbólicas virem moeda de troca para aqueles que desejam visitar e conhecer. De acordo com Yázigi (2003, p. 165) "Não parece estar claro para a maioria das municipalidades que o fenômeno geográfico do turismo está a alterar paisagens substancialmente, e que compete ao município papéis inalienáveis neste processo".

Portanto, e a partir das informações coletadas diante os moradores iratienses, percebeu-se que eles entendem que a responsabilidade em vigiar as paisagens parte da administração pública municipal: "A prefeitura tem o dever de cuidar do patrimônio público com zelo e responsabilidade” (B. L. M., 21 anos, mora no Centro).

Embora, o poder público tenha papel relevante na responsabilidade com a preservação das paisagens municipais, são os moradores que utilizam elas diariamente e, ou cotidianamente, fazendo assim com que eles também sejam agentes de proteção e 
zelo desses elementos. Esse encargo provém continuadamente para visitantes e turistas, pois os mesmos estão ali para apreciar a paisagem, não para agredir e usar indevidamente tal. Scherer (2002, p. 85) diz que é importante evidenciar os “[...] diferentes grupos de pessoas envolvidas quer em sua produção e utilização, quer em sua modificação e transformação".

P. F. C. (32 anos, mora no Bairro Canisianas) entende que a responsabilidade social sobre as paisagens parte da administração pública, contudo não esquiva a importância dos moradores locais no seu resguardo:

O poder público. Isso é dever do poder público: zelar pela segurança e condições de uso, aplicar verbas e investir. Isso não exime a comunidade local de cuidar desses espaços e não depredá-lo. Gonçalves Júnior é um distrito, e gosto dele todo: a zona rural e o pequeno centro da localidade. E aqui claro que o poder público tem fundamental responsabilidade de cuidar e zelar.

Portanto, a partir dessa questão proposta, levantou-se que o morador iratiense compreende que o zelo sobre as paisagens é de responsabilidade do governo municipal. Não houve exceção nas respostas, todos entendem que o organismo público municipal tem esse dever. Entretanto, o próprio morador e o visitante são atores primordiais na preservação e conservação dos recursos paisagísticos de uma municipalidade, pois eles que são os usuários. Logo, a união entre poder público, comunidade e turistas é relevante para evitar empecilhos que possam ocorrer sobre as paisagens.

- De que maneira esse lugar deve ser utilizada? Esse lugar mencionada poderia ser um atrativo histórico-cultural do município? $\mathrm{O} S \mathrm{Sr}$ (a) é a favor da divulgação dessa paisagem para o turismo?

Nessa questão, percebeu-se uma divisão entre as repostas dos moradores entrevistados, pois alguns entendem que as paisagens devem ser trabalhadas e fomentadas para o turismo, já outros percebem que não são potenciais turísticos, deste modo devem ser planejados para a população local. Por um lado:

Acho que seria interessante divulgar esses lugares para o turismo. Se tivéssemos mais atrativos na nossa cidade à economia se fortaleceria. Eu sou totalmente a favor da divulgação para o turismo pelo motivo pelo qual te falei. Assim vindo mais pessoas visitar nossa cidade ela ficaria reconhecida mais e viriam mais visitantes (P. H. D., 18 anos, mora no Bairro Rio Bonito).

Por outro: 
Eles têm o uso adequado: lazer e práticas de esportes. Não penso que poderia ser atrativo histórico-cultural ou tampouco de outra natureza, pois ele não tem atratividade para captar turistas, mas isso não os diminui, eles são importantes para quem vive em Irati. Preferiria que ele fosse um lugar da e para a comunidade, para manter a tranquilidade dele. Mas isso não quer dizer que não possa ou deva ser melhorado. Eventualmente Gonçalves Júnior poderia sim ser utilizado para divulgação/promoção turística.” (P. F. C., 32 anos, mora no Bairro Canisianas).

No primeiro caso, analisa-se que alguns entrevistados julgam como necessário a divulgação dessas paisagens para a captação de turistas, o que possivelmente proporcionará o desenvolvimento econômico da localidade. Dias e Pimenta (2005, p. 101) entendem que "[...] os elementos presentes no ambiente como um todo, principalmente os naturais e culturais, são os principais recursos socialmente valorizados e capazes de motivar o afluxo de turistas para as destinações".

No segundo caso, existem pessoas que entendem que as paisagens são recursos provenientes para o uso da comunidade, deixando assim de lado, a sua importância econômica e exaltando sua relevância social, ambiental e de lazer para os moradores iratienses. Para Castro (2002, p. 133) é errôneo apontar a paisagem somente para o turismo, pois "[...] quanto mais valorizada socialmente, mais valor o lugar adquire, seja para seus habitantes, seja para seus visitantes" (grifo da autora). Ou, então, na visão de Yázigi (2003, p. 70): "No entanto, é preciso ancorar-se no fato de que a paisagem interessa antes a seus habitantes e que só numa relação de estima deles pelo espaço é que, eventualmente, despertará o interesse de transeuntes, visitantes, turistas." A relação entre turista, comunidade e meio físico obrigatoriamente acontecerá, contudo o planejamento perante as paisagens foca, primeiramente, em atingir o residente e, em segundo plano, o visitante. Deste modo, é fundamental destacar que o fruto da atratividade de uma paisagem é proveniente do valor agregado pelos seus habitantes.

Tendo em vista, os principais atrativos e, também, paisagens turísticas de Irati, B. L. M. (21 anos, mora no Centro) diz: "Na Santa poderiam ser feitas excursões religiosas, podendo sim ser um atrativo histórico-cultural. O parque aquático deve ser divulgado a favor do turismo e lazer".

A partir das respostas coletadas, mostra-se que a maioria dos entrevistados, entende como benéfico o uso das paisagens para o turismo. Certamente, eles veem o turismo como um agente de desenvolvimento econômico do município e que pode 
encadear maior atratividade a esses elementos do meio. Portanto, eles não restringem a atividade turística, crêem que pode haver harmonia entre morador, turista e paisagem.

\title{
- Que imagem, lugar ou paisagem o Sr (a) propunha para divulgar o município para
} pessoa que tem interesse de conhecê-lo? E, qual o Sr (a) não recomendaria?

Muitas vezes, o que se vê concretamente em um município não necessariamente é mais encantador no imaginário social de um morador. Percepções abstratas cingem no pensamento do indivíduo, fazendo assim que a maior atratividade de um local esteja enraizada em, por exemplo, costumes e crenças de um povo.

Poderiam ser utilizadas imagens dos traços e legados étnicos da cidade, sobretudo polonesa e ucraniana, tais como alguma coisa de arquitetura, folclore e gastronomia. Não recomendaria as cachoeiras, pois elas não agregam diferencial competitivo para o destino (P. F. C., 32 anos, mora no Bairro Canisianas).

Deste modo, Monastirsky (2009, p. 331) entende que:

\begin{abstract}
Inicialmente, esse lugar deve apresentar um traço que seja considerado relevante para a memória coletiva. Quanto mais abrangente for o reconhecimento dessa memória por parte da população, mais válidas serão as ações impetradas sobre ele. Depois, a relação deste traço com o ambiente construído deve possibilitar e incentivar a manutenção da sua integridade simbólica e a percepção dos significados dos elementos que a compõem. Com essas características, o lugar possibilita ao indivíduo o (re) conhecimento da sua participação na cultura local, promove o bem estar social e contribui para o exercício de cidadania e, assim constituído, oferece à sociedade local e visitante, um espaço funcional para o desenvolvimento de ações educadoras e, conseqüentemente, turísticas.
\end{abstract}

Os traços estéticos de uma paisagem podem ser fatores de encanto para uma coletividade, contudo sua vinculação com o meio físico não necessariamente faz com que a exterioridade seja a principal imagem de um município. As pessoas interiorizam determinados elementos ali vivenciados (como, por exemplo, a gastronomia típica) e dotam de simbolismo e de significados culturais. A partir disso, para um morador local, o atrativo se faz presente na singularidade de sua cultura.

Eis, que existem aqueles que enxergam nos principais atrativos turísticos do município, locais propícios para a divulgação: "Proponho, hipoteticamente, uma divulgação com base nas imagens da Colina Nossa Senhora das Graças em conjunto com a do Parque Aquático. Um por ser local de visitação turística constante; outro por 
ser um lugar aconchegante e acolhedor para quem deseja passar um tempo ocioso." (T. F., 22 anos, mora no Centro). Ainda, A. S. G. (22 anos, mora no Centro) diz: “A Santa e o Parque Aquático são lugares que poderiam ser mais divulgados. Acho que o ginásio poderia passar por reformas antes de ser divulgado, algumas praças também, pois não se encontram em condições propícias para serem algo que chame atenção".

A relevância dos atrativos turísticos de Irati, apontada pelos entrevistados, proporciona também a seguinte reflexão: "cada paisagem é um fato singular cujo valor não se mantém constante em toda sua extensão" (BOULLÓN, 2002, p. 149). Ou seja, a percepção de um indivíduo é particular, ora o que tem valor para um, difere na concepção de outro.

$\mathrm{Na}$ oportunidade de apresentar o município para um conhecido ou então para um visitante o Morro da Santa e o Parque Aquático se destacam. Portanto, na visão da maioria dos entrevistados, os potenciais turísticos da cidade são aqueles mesmos fomentados pela administração turística municipal.

A partir dessas questões levantas foi possível perceber que o morador de Irati está satisfeito com o seu lugar vivido e vivenciado. Do mesmo modo, que este valora as paisagens presentes no município, possuindo um elo afetivo com os patrimônios paisagísticos e com o lugar.

Por ser uma cidade rodeada de serras, a beleza cênica é relevante, unindo esses recursos naturais, com construções contemporâneas e com elementos que marcam a história do município. Outro fator de destaque é os traços culturais europeus, principalmente ucranianos e poloneses, podendo ser percebido na culinária e no artesanato.

\section{CONSIDERAÇÕES FINAIS}

A atividade turística condiciona a criação novos lugares, de novas práticas socioespaciais, que serão fomentadas e praticadas determinadas formas de turismo, do mesmo modo, em que a população também usará. Assim, nascem lugares que, para gerações futuras, podem ser ambientes dotados de simbolismos, outrora, podem ocorrer danos à cultura pela implementação da atividade naquele local.

Em relação à paisagem ela é um elemento importante para a atração e desenvolvimento da atividade turística, enquanto um recurso mercadológico. Ela 
abrange modificação e imposição no espaço, seja a partir de uma ótica capitalista ou por ações provenientes da natureza, do mesmo modo, que envolve pesquisas sobre sua importância para um sujeito e/ou coletividade, no que tange ao seu valor histórico, cultural, afetivo, simbólico.

Entretanto, o turismo não é a atividade que mais movimenta a economia do município de Irati, existem dados que ele vem crescendo e se desenvolvendo, a partir de iniciativas privadas e do governo estadual e municipal. As ações governamentais e privadas concernem, essencialmente, nas exposições do turismo histórico e religioso, resgatando a cultura polonesa e ucraniana, bastante presente no município através do artesanato e gastronomia.

Nesse sentindo, a importância que se dá a essa atividade não é a realmente percebida perante aquelas cidades que são denominadas como turísticas ou, então, aquelas que procuram de alguma forma divulgar seus atrativos em cenário nacional ou internacional, como é o caso do município limítrofe, Prudentópolis. Em Irati, o apelo turístico parte, sobretudo, da Imagem de Nossa Senhora das Graças, que é reconhecida por pessoas do Brasil e de algumas partes do mundo, que são ligadas e interessadas pelo turismo histórico-cultural-religioso.

Exemplos como o Parque Aquático e o Morro da Santa, entendidos como atrativos turísticos do município, são espaços que recebem assiduamente os moradores do município, que por motivo de ordem social, praticam suas atividades esportivas e de lazer (no primeiro) e de cunho religioso e de contemplação (no segundo). A partir de observações assistemáticas nesses locais notou-se que no Parque Aquático não existe nenhuma prática turística e no Morro da Santa é irrisória a quantidade de pessoas que visitam com a finalidade turística.

Entre outros ambientes e paisagens intituladas como atrativos ou pontos turísticos do município notou-se, do mesmo modo, que não existe a procura por parte do turista, mas sim por parte dos moradores que utilizam os espaços e paisagens, tratados como turísticos, para alguma finalidade. Isso ocorre, principalmente, nos finais de semana. Até mesmo, as praças são entendidas pelo governo municipal como atrativos turísticos, e o que se vê são moradores utilizando para caminhadas, descanso, entretenimento, etc. 
Em geral, o turismo em Irati é invisível, inexistente. De modo que é um município ainda procurando entender os benefícios desta atividade, contudo, sem muitas perspectivas de crescimento ou desenvolvimento econômico. Essa afirmação pode ser constatada na divisão político-administrativa do município, pois o Departamento de Turismo está inserido dentro da Secretaria de Patrimônio Histórico, Turismo, Cultura, Lazer e Desportos, o qual tem por finalidade o desenvolvimento de projetos e a divulgação e promoção turística do município. Além disso, o município ainda não possui uma política pública para o Turismo.

Há ainda, muito, o que se fazer para que o turismo seja tratado como uma atividade de proeminência dentro da economia local. Conquanto, crê-se que a primeira ação a ser procedida é o estabelecimento de uma secretaria para o turismo, pois, a partir disso surgem maiores responsabilidades para àqueles ocupantes dos cargos préestabelecidos para essa repartição, consequentemente, uma política do turismo mais organizada e devidamente planejada.

A visão quanto ao planejamento existe por parte dos responsáveis pelo turismo municipal, mas ainda é inexistente tanto o turismo, como o planejamento turístico na localidade. Percebe-se, também, que há o interesse de operacionalizar prerrogativas para o desenvolvimento do turismo em Irati, porém esbarram em questões burocráticas, do mesmo modo, que a falta interesse da iniciativa privada para com essa atividade.

\section{REFERÊNCIAS}

AMORIM FILHO, O. B. Topofilia, topofobia e topocídio em Minas Gerais. In: DEL RIO, V.; OLIVEIRA, L. (Orgs.) Percepção ambiental: a experiência brasileira. São Paulo: Editora da UFSC, 1996. p.139-152.

BUTTIMER, A. Aprendendo o dinamismo do mundo-vivido. In: CHRISTOFOLETTI, A. (Org.) Perspectivas da Geografia. São Paulo, Difel, 1995. p. 165-193.

BACHELARD, G. La poética del espacio. Argentina: Fondo de Cultura Econômica, 2000.

CARLOS, A. F. A. O Lugar no/do mundo. São Paulo: Hucitec, 1996

CASTRO, I. E. Paisagem e turismo. De estética, nostalgia e política. In: YÁZIGI, E. (org.). Turismo e paisagem. São Paulo: Contexto, 2002, p. 121-140.

CLAVAL, P. A Geografia cultural. 3. ed. Florianópolis: Ed. UFSC, 2007.

FERREIRA, L. F. Acepções recentes do conceito de lugar e sua importância para o mundo Geo UERJ - Ano 15, n'. 24, v. 2, $2^{\circ}$ semestre de 2013

ISSN: 1415-7543 E-ISSN: 1981-9021

http://www.e-publicacoes.uerj.br/index.php/geouerj 
contemporâneo. Revista Território. Rio de Janeiro, UFRJ, ano V, n. 9 (jul/dez), 2000, p. 65-83.

FOUCAULT, M. As palavras e as coisas: uma arqueologia das ciências humanas. 8. ed. São Paulo: Martins Fontes, 1999.

GARCIA-MONTRONE, A. et al (2004): Práticas sócias, o que são? São Carlos: PPGE/UFSCar (material produzido pelos docentes da disciplina Práticas Sociais e Processos Educativos do Programa de Pós-Graduação em Educação da Universidade Federal de São Carlos).

HARVEY, D. Condição Pós-Moderna. São Paulo: Loyola, 1992.

From space to place and back again. In: Justice, nature and the geography of difference. Oxford: Blackwell, 1996, p. 291-326.

JOHNSTON, R. J. A question of place: exploring the practice of human geography. Oxford/Cambridge: Blackwell Publishers, 1991.

KOZEL, S. Comunicando e representando: mapas como construções socioculturais. In: SEEMANN, J. (Org.) A aventura cartográfica: perspectivas, pesquisas e reflexões sobre a cartografia humana. Fortaleza: Expressão Gráfica e Editora, 2005.

MACHADO, L. P. C. P. Paisagem valorizada: a Serra do Mar como espaço e como lugar. In: DEL RIO, V.; OLIVEIRA, L. de (orgs.). Percepção ambiental: a experiência brasileira. São Carlos: EdUFScar/Studio Nobel, 1996, p. 97-119.

MONASTIRSKY, L. B. Espaço urbano: memória social e patrimônio cultural. Revista Terra Plural (on-line). Ponta Grossa. Vol. 2, n. 2, jul-dez, 2009.

PIAGET, J. Seis estudos de psicologia. 21. ed. Rio de Janeiro: Forense Universitária, 1995.

RELPH, E. Place and Placenessless. London, Pion, 1980.

SANTOS, M. A aceleração contemporânea: tempo mundo e espaço mundo. In:

et al. (orgs.). O novo mapa do mundo: fim de século e globalização. São Paulo: Hucitec, 1993, p.15-22.

SANTOS, M. A natureza do espaço: técnica e tempo, razão e emoção. 4. ed. São Paulo: Editora da USP, 2006.

Por uma outra globalização: do pensamento único à consciência universal. 15 . ed. Rio de Janeiro: Record, 2008.

SCHERER, R. Paisagem urbanística, urbanização pós-moderna e turismo. In: YÁZIGI, E. Turismo e paisagem. São Paulo: Contexto, 2002, p. 83-105.

TUAN, Y. F. Espaço e Lugar: a perspectiva da experiência. São Paulo: DIFEL, 1983.

YÁZIGI, E. A alma do lugar: turismo, planejamento e cotidiano em litorais e montanhas. 2. ed. São Paulo: Contexto, 2001.

A importância da paisagem. In: YÁZIGI, E. Turismo e paisagem. São Paulo:

Geo UERJ - Ano 15, n'. 24, v. 2, $2^{\circ}$ semestre de 2013

ISSN: 1415-7543 E-ISSN: 1981-9021

http://www.e-publicacoes.uerj.br/index.php/geouerj 
Contexto, 2002, p. 11-28.

Turismo: uma esperança condicional. 3. Ed. São Paulo: Global, 2003.

Artigo recebido para publicação em junho de 2013.

Artigo aceito para publicação em julho de 2013. 